\title{
Kajian Distribusi Pendapatan Petani Padi Ciherang (Oryza sativa) di Kecamatan Haruyan Kabupaten Hulu Sungai Tengah Provinsi Kalimantan Selatan
}

\section{(Income Distribution Study of Farmers Ciherang Paddy (Oryza sativa) in Haruyan District Hulu Sungai Tengah Regency Kalimantan Selatan Province)}

\author{
Ahmad Suhaimi ${ }^{1)} \&$ Nurlenny Khatimah ${ }^{2)}$ \\ Program Studi Agribisnis, Sekolah Tinggi Ilmu Pertanian Amuntai \\ 1)ahmad99ec@gmail.com \\ ${ }^{2)}$ lenny@gmail.com
}

\begin{abstract}
ABSTRAK
Penelitian ini bertujuan untuk mengetahui pendapatan, dan menganalisis distribusi pendapatan petani padi Ciherang di Kecamatan Haruyan, Kabupaten Hulu Sungai Tengah Provinsi Kalimantan Selatan. Penelitian dilakukan selama 3 bulan dari bulan Juni - Agustus 2014. Penelitian Menggunakan desain penelitian deskriptif, unit analisis yang diteliti adalah petani padi Ciherang. Metode pengambilan sampel ini dilakukan dengan metode purposive sampling. Hasil penelitian menunjukkan bahwa, pendapatan bersih petani berkisar antara $R p 84.097$ - Rp16.992.279. Hasil analisis distribusi pendapatan petani padi Ciherang melalui perhitungan angka yang diperoleh rasio Gini 0,499, hal ini menunjukkan distribusi pendapatan petani padi Ciherang berada pada level kesenjangan sedang. Ketimpangan distribusi pendapatan diduga karena penggunaan lahan yang kurang optimal, kurangnya penggunaan alat atau mesin yang tepat guna serta kurangnya peran penyuluh dalam memberikan arahan kepada petani bagaimana budidaya yang baik dan tepat.
\end{abstract}

Kata kunci: Pendapatan, petani, padi, ciherang, distribusi.

\section{ABSTRACT}

This study aims to determine income, and income distribution of rice farmers Ciherang paddy in Haruyan District Hulu Sungai Tengah Regency Kalimantan Selatan Province. Research carried out for 3 months from June to August 2014. Research The use descriptive research design, analysis units studied were rice farmers Ciherang. This method of sampling is done with purposive sampling method. The results showed that, farmers' net income ranging from $R p 84097$ - Rp 16,992,279. The results of the analysis of income distribution Ciherang rice farmers through the calculation of figures obtained Gini ratio 0.499, this hi menunjukkandistribusi Ciherang rice farmers' income is at the level of the gap being. Inequality of income distribution is suspected because of a less than optimal use of land, lack of use of a tool or machine that is appropriate and lack of extension's role in providing guidance to farmers how good and proper cultivation.

Keywords: Income, farmers, rice, ciherang, distribution.

\section{PENDAHULUAN}

Masalah besar yang dihadapi negara sedang berkembang adalah disparitas (ketimpangan) distribusi pendapatan dan tingkat kemiskinan. Tidak meratanya distribusi pendapatan memicu terjadinya ketimpangan pendapatan yang merupakan awal dari munculnya masalah kemiskinan. Membiarkan kedua masalah tersebut berlarut-larut akan semakin memperparah keadaan, dan tidak jarang dapat menimbulkan konsekuensi negatif terhadap kondisi sosial dan politik.

Perbedaan pendapatan timbul karena adanya perbedaan dalam kepemilikan sumber daya dan faktor produksi terutama kepemilikan barang modal (capital stock). Pihak (kelompok masyarakat) yang memiliki faktor produksi yang lebih banyak akan memperoleh pendapatan yang lebih banyak pula.

Tingginya Produk Domestik Bruto (PDB) suatu negara belum tentu mencerminkan meratanya terhadap 
distribusi pendapatan. Kenyataan menunjukkan bahwa pendapatan masyarakat tidak selalu merata, bahkan kecendrungan yang terjadi justru sebaliknya. Distribusi pendapatan yang tidak merata akan mengakibatkan terjadinya disparitas. Semakin besar perbedaan pembagian pembangunan, semakin besar pula disparitas distribusi pendapatan yang terjadi. Indonesia yang tergolong dalam negara yang sedang berkembang tidak terlepas dari permasalahan ini.

Salah satu indikator penting untuk mengetahui kondisi ekonomi di suatu wilayah dalam suatu periode tertentu ditunjukkan oleh data Produk Domestik Regional Bruto (PDRB). Angka PDRB Kabupaten Hulu Sungai Tengah dari tahun ke tahun terus mengalami kenaikan.PDRB Hulu Sungai Tengah dalam 5 tahun terakhir dapat dilihat pada tabel 1 di bawah ini:

Tabel 1 : Produk Domestik Regional Bruto (PDRB) HST (dalam juta rupiah)

\begin{tabular}{cccc}
\hline No & Tahun & PDRB Atas Dasar HB & PDRB Atas Dasar HK \\
\hline 1 & 2008 & 1.646 .595 & 978.131 \\
2 & 2009 & 1.912 .498 & 1.044 .319 \\
3 & 2010 & 2.147 .657 & 1.093 .972 \\
4 & 2011 & 2.406 .823 & 1.163 .269 \\
5 & 2012 & 2.666 .215 & 1.225 .542 \\
\hline
\end{tabular}

Sumber : BPS Kab. Hulu Sungai Tengah (2013)

PDRB sangat berkaitan dengan hasil produksi lokalitas mata masyarakat.Hasil produksi padi diseluruh kecamatan di Kabupaten Hulu Sungai Tengah, Kecamatan Haruyan merupakan salah satu kecamatan penyumbang padi terbesar selain kecamatan Pandawan, dan Labuan Amas Utara. Ketiga daerah ini menyumbang 53\% dari keseluruhan produksi. Pandawan dengan 41,6 ribu ton disusul kecamatan Haruyan 34,8 ribu ton dan Labuan Amas Utara 24 ribu ton pertahun.

Masyarakat di Kecamatan Haruyan hampir semuanya bekerja dibidang pertanian, dan pekerjaan ini merupakan pekerjaan utama mereka, tidak dapat di pungkiri pula bahwa sebagian dari mereka masih hidup di bawah garis kemiskinan. Kondisi ini bila tidak dapat diatasi akan menimbulkan ketimpangan. Masalah pokok yang timbul dari hal tersebut terutama dalam hal pendapatan. Dalam studinya Bank Dunia mengklasifikasikan kelas menengah berdasarkan pengeluaran perkapita yang direkam dari survei sosial ekonomi nasional/Susenas yang dilakukan Badan Pusat Statistik. Cara membedakan kelompok miskin dan kelas menengah dengan memilah jumlah pengeluaran individu perhari. Yang dimaksud kelompok miskin bila pengeluaran individu perhari kurang dari US\$ 2. Sedangkan kelas menengah terbagi atas empat kelas, yaitu kelas pengeluaran Rp 1 juta sampai Rp 1,5 juta perbulan (kelas menengah bawah). Kedua, kelas pengeluaran $\mathrm{Rp}$ 1,5 sampai 2,6 juta perbulan. Ketiga, kelas pengeluaran $\mathrm{Rp} 2,6$ juta sampai 5,2 juta perbulan (menengah tengah). Dan kelas keempat yaitu pengeluaran $\mathrm{Rp} 5,2$ juta hingga $\mathrm{Rp} 6$ juta perbulan (menengah atas). Selebihnya adalah kelompok berkecukupan (BPS Kalsel, 2010).

Usahatani padi yang merupakan pekerjaan utama masyarakat Haruyan yang merupakn $73 \%$ dari padi yang diusahakan di wilayah ini adalah padi Ciherang, dikarenakan faktor alam yang cukup mendukung dalam budidaya ini.

Produksi padi Ciherang di kecamatan Haruyan dari tahun 2010 sampai tahun 2012 terus mengalami peningkatan. Pada tahun 2010 produksi padi ciherang sebesar 20274,29 ton, tahun 2011 sebesar 23726,46 ton dan pada tahun 2012 sebesar 25395,97 ton.

Tingkat pendapatan suatu kelompok masyarakat terutama di daerah pedesaan 
masih dianggap sebagai tolak ukur kesejahteraan dan status sosial. Semakin tinggi tingkat pendapatan seseorang biasanya memiliki kesejahteraan dan status sosial yang semakin tinggi pula.

Penelitian ini bertujuan untuk mengetahui pendapatan, dan menganalisis distribusi pendapatan petani padi Ciherang di Kecamatan Haruyan, Kabupaten Hulu Sungai Tengah Provinsi Kalimantan Selatan.

\section{METODE PENELITIAN}

\section{Desain Penelitian dan Unit Analisis}

Penelitian ini menggunakan desain penelitian deskriptif, dilakukan dengan tujuan utama untuk memberikan gambaran atau deskripsi tentang satu keadaan secara objektif. Unit analisis yang diteliti adalah petani padi Ciherang di Kecamatan Haruyan Kabupaten Hulu Sungai Selatan selama 3 bulan terhitung dari bulan Juni - Agustus 2014.

\section{Metode Pengumpulan Data}

Metode pengambilan sampel dilakukan dengan metode Purposive sampling. Teknik penarikan sampel ini berorientasi kepada pemilihan sampel di mana populasi dan tujuan yang spesifik dari penelitian diketahui oleh peneliti sejak awal. Dalam pelaksanaannya, peneliti dapat memanfatkan pengetahunnya dan pengalamannya dalam menentukan responden penelitian (Zuriah, 2007).

Berdasarkan hal tersebut dipilih 5 desa sebagai sampel yang dianggap mewakili (refresentatif) karena desa tersebut adalah desa yang terbayak jumlah petaninya dari 17 desa yang ada di kecamatan Haruyan. Desa tersebut adalah desa Panggung, desa Teluk Mesjid, desa Haruyan, Desa Barikin dan desa Andang. Dari 5 desa tersebut dipilih sebanyak 50 orang responden dan setiap desa diwakili oleh 10 orang responden.

\section{Analisis Data}

Analisis Data menjawab tujuan pertama yaitu besarnya pendapatan petani padi dengan menggunakan analisis kuantitatif, untuk melihat seberapa besar pendapatan bersihpetani padi Ciherang dalam usahataninya dengan menggunakan rumus:

- Biaya total :

$\mathrm{TC}=$ Biaya implisit + biaya eksplisit

- Pendapatan Kotor :

TR $=$ P (Harga Padi) X Q (Produksi Padi)

- Pendapatan bersih

$\Pi=\mathrm{TR}-\mathrm{TC}$

Dimana :

$\mathrm{TR}=$ Pendapatan Kotor

$\mathrm{TC}=$ Biaya Total Produksi

Analisis data untuk menjawab tujuan kedua yaitu mengetahui distribusi pendapatan petani padi dengan menggunakan metode analisis kuantitatif, metode ini untuk melihat distribusi pendapatan petani padi di kecamatan Haruyan digunakan rumus gini ratio sebagai berikut:

Keterangan:

$$
\mathrm{G}=1-\Sigma \mathrm{Pi}(\mathrm{Ii}+\mathrm{Ii}-1)
$$

$\mathrm{Pi}=\%$ penerima pendapatan kelompok petani padi ke-i $\mathrm{Ii}=\%$ Kumulatif pendapatan yang diterima kelompok petani padi ke-i

Adapun untuk mengetahui tingkat ketimpangan pendapatan menurut Rahajdja dan Manurung (2005) dapat dilihat pada patokan nilai koefisien gini yaitu nilai koefisien $<0,3$ distribusi pendapatan adalah tingkat ketimpangan rendah, $0,3-0,5$ distribusi pendapatan adalah tingkat ketimpangan sedang, > 0,5 distribusi pendapatan adalah tingkat ketimpangan tinggi. 


\section{HASIL DAN PEMBAHASAN}

\section{Hasil}

\section{Pendapatan Rumah Tangga Petani Padi Ciherang}

Tabel 2. Pendapatan petani padi tahun 2014.
Data pendapatan petani pada saat penelitian ini, bersumber dari pendapatan utama petani padi Ciherang.

\begin{tabular}{ccc}
\hline Kelompok Pendapatan (Rupiah) & Jumlah Responden & \%tase $(\%)$ \\
\hline$<1.000 .000$ & 14 & 28 \\
$1.000 .000-1.999 .999$ & 8 & 16 \\
$2.000 .000-2.999 .999$ & 11 & 22 \\
$3.000 .000-4.000 .000$ & 7 & 14 \\
$>4.000 .000$ & 10 & 20 \\
\hline Jumlah & 50 & 100 \\
\hline
\end{tabular}

Berdasarkan Tabel 2 di atas, terlihat bahwa pendapatan petani responden dari usaha tani padi Ciherang sebanyak 14 responden yang berpendapatan kurang dari $\mathrm{Rp} 1.000 .000$ atau sebesar $28 \%, 8$ responden yang berpendapatan antara $\mathrm{Rp}$ 1.000.000-1.999,999 atau sebesar $16 \%, 11$ responden berpendapatan antara Rp 2.000.000-2.999,999 atau sebesar $22 \%, 7$ responden berpendapatan antara Rp 3.000.000-4.000.000 atau sebesar $14 \%$ dan 10responden yang berpendapatan lebih dari Rp 4.000.000 atau sebesar $20 \%$.

\section{Ketidakmerataan Pendapatan (Gini Ratio) Petani Padi Ciherang}

Mengetahui ketidakmerataan distribusi pendapatan petani padi Ciherang di kecamatan Haruyan dapat dilihat pada Tabel 3, perhitungan golongan pendapatan responden di Kecamatan Haruyan secara gini ratio seperti dibawah ini:

Tabel 3. Perhitungan golongan pendapatan responden di Kecamatan Haruyan secara gini ratio tahun 2014.

\begin{tabular}{|c|c|c|c|c|c|}
\hline \multirow{2}{*}{ No (k) } & \multirow{2}{*}{$\begin{array}{c}\text { Penerima } \\
\text { Pendapatan }(\%)\end{array}$} & \multicolumn{2}{|c|}{ Pendapatan Diterima (I) } & \multicolumn{2}{|c|}{$\%$ Kumulatif Pendapatan Diterima } \\
\hline & & $(\mathrm{Rp})$ & $(\%)$ & Kuartil & Desil \\
\hline 1 & & 84.097 & 0,13 & & \\
\hline $2(\mathrm{k}-1)$ & 10 & 269.780 & 0,41 & & 0,54 \\
\hline 3 & & 327.283 & 0,50 & & \\
\hline $4(k-2)$ & 10 & 530.624 & 0,81 & 1,85 & 1,85 \\
\hline 5 & & 548.553 & 0,83 & & \\
\hline $6(k-3)$ & 10 & 1.292 .653 & 1,97 & & 4,65 \\
\hline 7 & & 1.316 .535 & 2,00 & & \\
\hline $8(k-4)$ & 10 & 1.885 .884 & 2,87 & 9,52 & 9,52 \\
\hline 9 & & 1.921 .635 & 2,92 & & \\
\hline $10(\mathrm{k}-5)$ & 10 & 2.283 .338 & 3,48 & & 15,92 \\
\hline 11 & & 2.312 .519 & 3,52 & & \\
\hline $12(\mathrm{k}-6)$ & 10 & 2.900 .541 & 4,41 & 23,85 & 23,85 \\
\hline 13 & & 2.904 .541 & 4,42 & & \\
\hline $14(\mathrm{k}-7)$ & 10 & 3.099 .454 & 4,72 & & 32,99 \\
\hline 15 & & 3.208 .382 & 4,88 & & \\
\hline $16(\mathrm{k}-8)$ & 10 & 3.791 .527 & 5,77 & 43,64 & 43,64 \\
\hline 17 & & 4.436 .028 & 6,75 & & \\
\hline $18(\mathrm{k}-9)$ & 10 & 6.866 .058 & 10,45 & & 60,84 \\
\hline 19 & & 8.735 .847 & 13,3 & & \\
\hline $20(\mathrm{k}-10)$ & 10 & 16.992 .275 & 25,86 & 100 & 100 \\
\hline & alah & 65.707 .554 & 100 & & \\
\hline
\end{tabular}




\section{Perhitungan Bilangan Gini}

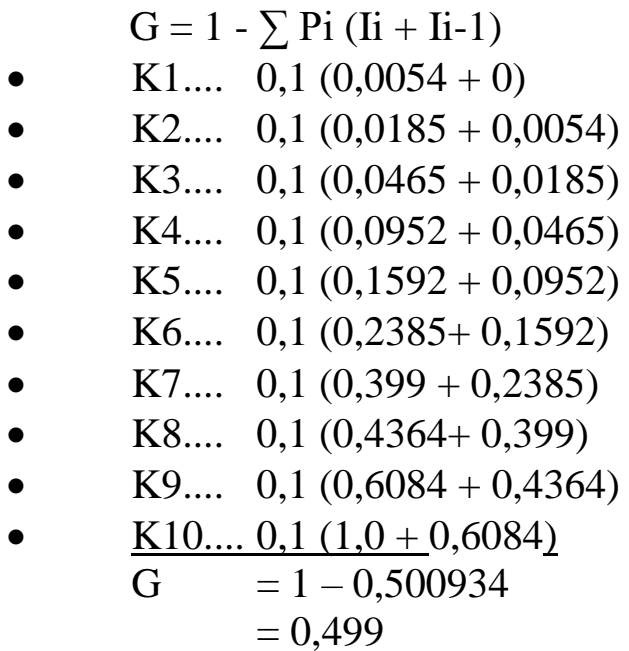

Hasil perhitungan Gini Ratio untuk total pendapatan petani padi Ciherang di Kecamatan Haruyan diperoleh angka sebesar 0,499

\section{Distribusi Pendapatan Petani Padi Ciherang}

Berdasarkan penilaian pada distribusi pendapatan petani padi Ciherang yang ada di Kecamatan Haruyan melalui perhitungan gini ratio maka akan lebih dipertajam dengan melihat proporsi pembagian pendapatan diantara kelompok petani dan total penerima pendapatan petani, dapat dilihat pada Tabel 4 .

Tabel 4. Proporsi pembagian total pendapatan di Kecamatan Haruyan

\begin{tabular}{clccc}
\hline No & Kelompok Petani Penerima & $\begin{array}{c}\text { Total } \\
\text { Penerima (Rp) }\end{array}$ & \%tase (\%) & $\begin{array}{c}\text { Kumulatif. } \\
\text { Pendapatan }\end{array}$ \\
\hline 1. & Kelompok 20 \% Pertama & 5.794 .771 & 3,46 & 3,46 \\
2. & Kelompok 20\% Kedua & 13.580 .882 & 8,11 & 11,57 \\
3. & Kelompok 20\% Ketiga & 28.450 .713 & 16,99 & 28,56 \\
4. & Kelompok 20\% Keempat & 23.911 .418 & 14,28 & 42,84 \\
5. & Kelompok 20\% Kelima & 95.757 .226 & 57,17 & 100 \\
\hline & Jumlah & 167.495 .010 & 100 & \\
\hline
\end{tabular}

Berdasarkan tabel di atas, bahwa kelompok $20 \%$ pertama petani responden memperoleh pendapatan sebesar $3,46 \%$. Kelompok 20\% ke-dua memperoleh pendapatan sebesar $8,11 \%$. Kelompok $20 \%$ ke-tiga memperoleh pendapatan sebesar 16,99\%. Kelompok 20\% ke-empat memperoleh pendapatan sebesar $14,28 \%$.
Sedangkan $20 \%$ terakhir kelompok petani responden memperoleh pendapatan sebesar $57,17 \%$.

Hasil analisis ketimpangan distribusi pendapatan petani padi Ciherang di Kecamatan Haruyan dapat dilihat dengan menggunakan kurva Lorenz seperti terlihat pada gambar berikut ini.

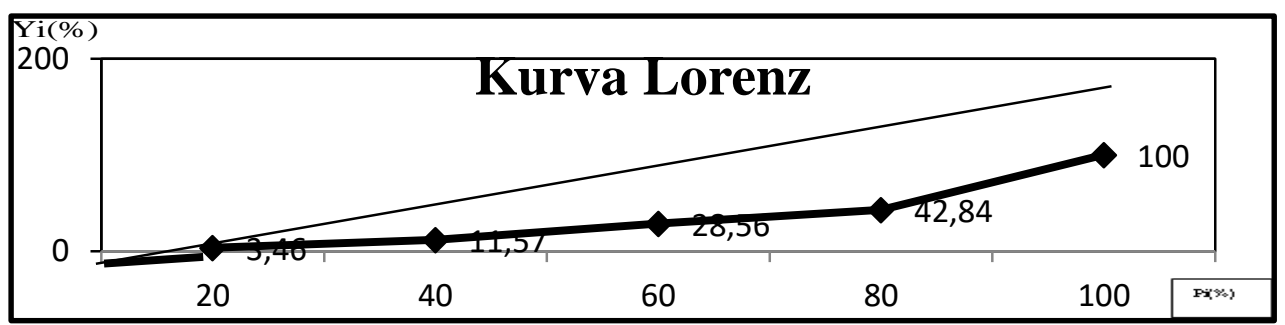

Gambar 5. Ketimpangan distribusi pendapatan menggunakan kurva lorenz

Ket:Yi= Kumulatif Pendapatan

$\mathrm{Pi}=$ KumulatifPenduduk

Pada gambar di atas, terlihat bahwa distribusi pendapatan petani padi di kecamatan Haruyan menurut patokan nilai koefisien gini adalah berada pada tingkat ketimpangan yang sedang.

Ketidakmerataan pendapatan dapat dilihat pada patokan nilai koefisien gini 
yaitu jika $<0,3$ tingkat ketimpangan rendah, jika0,3-0,5tingkat ketimpangan sedang, dan jika >0,5tingkat ketimpangan tinggi.

Pada gambar di atas terlihat 20\% kelompok pertama mendapatkan \%tase

kumulatif pendapatan sebesar 3,46\%, kelompok $20 \%$ kedua mendapatkan $11,57 \%$, kelompok $20 \%$ ketiga mendapatkan $28,56 \%$, kelompok $20 \%$ keempat mendapatkan $42,84 \%$ dan kelompok $20 \%$ kelima mendapatkan $100 \%$.

\section{Pembahasan}

\section{Pendapatan}

Pendapatan yang diterima petani padi Ciherang di Kecamatan Haruyan dari hasil penjumlahan total usahatani padi Ciherang berkisar antara Rp, 84.000 sampai dengan Rp 16.992.275. Dari hasil keseluruhan pendapatan responden diperoleh Rata-rata pendapatan responden tersebut adalah Rp 3.349.900 per usahatani.

Yanti (2009) di dalam penelitiannya yang dilakukan di Balangan pada 110 responden menyebutkan pendapatan yang diperoleh responden adalah berkisar antara Rp 4.950.000,- per tahun sampai Rp 130.000.000,- per tahun, dengan rata-rata pendapatan yang diperoleh adalah $\mathrm{Rp}$ 22.679.091,- per tahun per rumahtangga atau Rp 1.889.924 per bulan per rumahtangga.

Perbedaan pendapatan yang diterima bisa disebabkan oleh cara mereka mengelola usahatani dan juga perbedaan faktor-faktor yang diduga mempengaruhi pendapatan petani tersebut. Faktor yang dimasksud di sini adalah faktor ekonomi dan sosial petani.

\section{Ketidakmerataan pendapatan (gini ratio)}

Hasil perhitungan gini ratio untuk total pendapatan di kecamatan Haruyan diperoleh angka sebesar 0,499. Berdasarkan kriteria gini ratio yang dikemukakan oleh Oshima 2005, angka yang diperoleh tersebut menunjukkan bahwa tingkat distribusi pendapatan petani padi Ciherang berada pada tingkat ketimpangan yang sedang.

Handayani (2013) menyebutkan perhitungan gini ratio untuk total pendapatan petani karet di Kecamatan Paringin diperoleh angka sebesar 0.37. Artinya tingkat ketidakmerataan sedang. Angka gini ratio ini mencerminkan bahwa distribusi pendapatan di Kecamatan Paringin bisa dikatakan cukup merata.

Firiani (2013) menyebutkan Hasil perhitungan gini ratio untuk total pendapatan di Kecamatan Batang Alai Selatan diperoleh angka sebesar 0,4216. Berdasarkan kriteria gini ratio yang dikemukakan oleh Suyatno tahun 2012, angka yang diperoleh tersebut menunjukkan bahwa tingkat distribusi pendapatan petani Cabe Besar berada pada kategori sedang.

Membandingkan dari hasil ketiga penelitian tersebut dapat dikatakan bahwa hasil perhitungan gini ratio satu daerah dengan daerah lain itu berbeda. Ada yang rendah namun adapula yang nilainya tinggi, namun ketiga penelitian tersebut masih berada di katagori tingkat ketimpangan yang sedang. Perbedaan nilai ini ratio terutama dipengaruhi oleh tingkat produktivitas masyarakat.

\section{Distribusi pendapatan}

Penelitian di Kecamatan Haruyan pada Tabel 13 di atas menunjukkan bahwa distribusi pendapatan petani padi Ciherang adalah $40 \%$ kelompok petani responden berpendapatan terendah memperoleh pendapatan sebesar 11,57\%. Petani responden kelompok $40 \%$ kedua memperoleh pendapatan sebesar $31,27 \%$. Sedangkan 20 kelompok petani responden berpendapatan $57,17 \%$.

Handayani (2013) menyebutkan dalam penelitiannya Distribusi pendapatan petani karet di Balangan menjelaskan bahwa $40 \%$ kelompok petani responden berpendapatan terendah di Kecamatan Paringin memperoleh pendapatan sebesar 25,62\%. Petani responden kelompok $40 \%$ kedua memperoleh pendapatan sebesar $56,50 \%$. Sedangkan 20 kelompok petani responden berpendapatan $17,85 \%$.

Dua penelitian tersebut terlihat perbedaan antara $40 \%$ kelompok pertama, $40 \%$ kelompok kedua dan $20 \%$ kelompok ketiga. Hal ini diduga hasil produksi yang 
berbeda sehingga pendapatan yang diterima petanipun berbeda.

Faktor penyebab kesenjangan distribusi pendapatan karena pemanfaatan lahan yang kurang optimal, seperti seperti jarak tanam atau sistem tanam yang lebih baik contohnya menggunakan sistem tanam jajar legowo, penngunaan alat atau mesin yang tepat guna yang dapat disesuaikan dengan keaadan lahan tersebut agar dapat lebih menghemat waktu dan tenaga dan juga menambah hasil produksi dan terakhir adalah kurangnya peran penyuluh dalam memberikan arahan pada petani bagaiman budidaya yang baik dan tepat agar petani dapat meningkatkan hasil produksi padinya.

\section{KESIMPULAN}

Pendapatan bersih responden berkisar antara Rp 84.097 - Rp 16.992.279. Pendapatan bersih petani dari yang terendah hingga tertinggi cukup signifikan, dikarenakan petani kadang tidak memperhitungkan biaya implisit. Ketidakmerataan pendapatan petani padi ciherang di Kecamatan Haruyan melalui perhitungan gini ratio diperoleh angka 0,499066. Hasil perhitungan dari angka gini ratio angka tersebut menunjukkan distribusi pendapatan petani padi ciherang di Kecamatan Haruyan berada pada tingkat kesenjangan sedang.

\section{DAFTAR PUSTAKA}

Badan Pusat Statistik HST. 2013. Statistik Daerah Kecamatan Haruyan 2013. Kabupaten Hulu Sungai Tengah.

Fitriani. 2013. Kajian kondisi sosial ekonomi dan distribusi pendapatan pada petani cabe besar di Kecamatan Batang Alai Selatan Kabupaten Hulu Sungai Tengah. Skripsi. Sekolah Tinggi Ilmu Pertanian Amuntai.

Handayani, R. 2013. Kajian kondisi sosial ekonomi petani karet (Hevea braziliensis) di Kecamatan Paringin
Kabupaten Balangan. Skripsi Sekolah Tinggi Ilmu Pertanian Amuntai

Rahardja, P. dan Manurung, M. 2005. Teori Ekonomi Makro. Universitas Indonesia. Jakarta.

Yanti, N. D. 2009. Pendapatan dan distribusi pendapatan masyarakat desa sekitar usaha pertambangan di Kabupaten Balangan. http://alulum.baak.web.id . diakses 04 Maret 2014.

Zuriah, N. 2007. Metodologi Penelitian Sosial dan Pendidikan. PT Bumi Aksara. Jakarta. 